\title{
A Framework for the Selection of Projects at the County Level in Croatia
}

\author{
Ljudevit Krpan* \\ Drago Pupavac* \\ Robert Maršanić ${ }^{* * *}$
}

\author{
https://doi.org/ 10.31297/hkju.21.2.6 \\ UDK $\quad 35.072 .2: 352 / 353$ \\ $35.073 .52: 352 / 353(497.5)$ \\ $336.14: 352 / 353(497.5)$ \\ Preliminary scientific report / prethodno znanstveno priopćenje \\ Received/primljeno: 06.11.2020. \\ Accepted / prihvaćeno: 26.03.2021.
}

This paper presents a framework for regional self-government units for the selection of projects expected to have a substantial positive effect on the socio-economic characteristics of the broader community. The previous experience of administrative bodies at all levels (national, regional and local) indicates that the decision to implement certain

* Ljudevit Krpan, Primorsko-goranska County, Rijeka, Croatia \& Full Professor, University North, Koprivnica, Croatia (Primorsko-goranska županija \& redoviti profesor, Sveučilište Sjever, Koprivnica, Hrvatska, e-mail: ljudevit.krpan@unin.hr).

ORCID ID: https://orcid.org/0000-0002-4355-7912

${ }^{* *}$ Drago Pupavac, High School Professor, Polytechnic of Rijeka, Rijeka, Croatia (profesor visoke škole, Veleučilište u Rijeci, Rijeka, Hrvatska, e-mail: drago.pupavac@veleri.hr).

ORCID ID: https://orcid.org/0000-0002-2201-0598

*** Robert Maršanić, Assistant Professor, University North, Koprivnica, Croatia (docent, Sveučilište Sjever, Koprivnica, Hrvatska, e-mail: rmarsanic@unin.hr).

ORCID ID: https://orcid.org/0000-0001-7193-5389 
project and programme activities was primarily based on political decision-making principles and a voluntarist approach. With the adoption of the acquis communautaire, the Republic of Croatia has provided legal prerequisites for the selection and implementation of projects based on established criteria, with the criterion of impact on the quality of life and development usually being the dominant one. Therefore, the goal of this paper is to describe the framework and procedure of the evaluation and selection of public projects at the regional level, which can easily be applied to decision-making at both the national and local levels.

Keywords: project management, public projects, regional self-government unit, public project selection, regional development

\section{Introduction}

Pursuant to the Regional Development Act (Official Gazette, 147/14, 123/17, 118/18 hereinafter: Act), regional self-government units are carriers of regional development planning. Accordingly, they are responsible for creating the (pre)conditions required to enable the delivery of projects that will have the greatest overall socio-economic and development impact, and they must ensure the optimal spending of budget resources that will provide the greatest benefit for the community. Hence, a well-designed process (Džinić, 2017) is needed for the collection, evaluation, and registration of project proposals in the County Database of Development Projects, as well as for nominating project proposals that are of importance to regional and local self-government units and will be (co-)financed from the budget. The purpose of this paper is to present a model for an effective selection of projects financed from the budgetary resources of local and regional self-government units.

Based on theoretical and practical research, this paper aims to put forward an optimal model for the collection, evaluation, and selection of projects and project ideas, their registration in the County Database of Development Projects, and their (co-)financing from the budgetary resources of regional and local self-government units. 


\section{Legal Framework for the Selection of Projects for Co-financing in the Regional and Local Self-Government}

In order to perceive the overall selection possibilities of projects to be (co-)financed from budgetary resources, the overall legal framework is analysed. It consists primarily of laws and secondary legislation from the domain of regional development and finances (budget preparation and financing of local and regional self-government units). The legal framework is predefined by the strategic development documents that every regional and local self-government adopts to create a long-term basis for decision-making regarding budgetary financing programmes.

\subsection{The Regional Development Act and Secondary Legislation}

The Regional Development Act regulates, among other things, the objectives and principles of regional development management in the Republic of Croatia, the regional development policy planning documents, as well as the bodies responsible for regional development management. What has been highlighted as the fundamental goal of the regional development policy is the objective of boosting the socio-economic development of Croatia by creating conditions that will allow all parts of the country to strengthen their competitiveness and to tap into their developmental potential.

The Act specifies that the regional development policy shall be implemented under the principles of partnership and cooperation, typically in consultation with the partnership council (whose appointed members belong to the private, public, and civil sectors of the area in question). In addition to the national level, also recognised are the statistical regional level (NUTS II regions), the county level, and the urban agglomeration level.

In order to coordinate the regional development policy more effectively, the Act stipulates that at the level of a statistical region, a development agreement for an area of at least three regional self-government units may be concluded. The development agreement sets down the priorities of development at the state and county levels and the level of urban areas (Art. $23 / 3$ and 4). Strategic projects of regional development that contribute to the development of the area are also identified, and the resources needed for the implementation of the development agreement are planned. 
The Act specifically stipulates the strategic planning of regional development and the planning documents of the regional development policy. ${ }^{1}$ It underlines that the development programme plans enacted by local and regional self-government units pursuant to the Budget Act must be in accordance with the County Development Strategy. In turn, the County Development Strategy must be in accordance with the planning documents of the regional development policies at the higher level, i.e., the Regional Development Strategy of the Republic of Croatia.

Furthermore, to ensure the effective planning and implementation of the regional development policy, the Act stipulates the establishment of a central electronic database of development projects and development indicators. The role of the database is to keep all project proposals at the national level in one place, permanently and without criteria.

\subsection{The Budget Act and Secondary Legislation}

The Budget Act (Official Gazette, 87/08, 136/12, 15/15, Art. 45/3) governs the basic budgetary processes and defines the basic preconditions for budget formulation. The process of budget formulation at the regional and local level begins with the adoption of the Economic and Fiscal Policy Guidelines for a three-year period. The Government of the Republic of Croatia adopts them on the basis of strategic plans, the National Reform Programme, the Convergence Programme, and specific recommendations of the Council of the European Union for the Republic of Croatia. Based on the three-year Economic and Fiscal Policy Guidelines and the instructions for drawing up the state budget, the Ministry of Finance compiles instructions for drawing up the budgets of local and regional self-government units. In these instructions, the elaboration of a prescribed methodology for budgeting and development of financial plans for budget beneficiaries of the local and regional self-government units holds a key place.

Notably, the Budget Act stipulates that the Croatian Government shall adopt the Regulation on the Evaluation Method and Investment Project Authorisation Procedure. The regulation is still pending.

The Budget Act (Art. 16/4) defines the development programme plan as a document of local and regional self-government units, drawn up for a

${ }^{1}$ Cf. Chapter 3, Strategic framework for the implementation of projects in local and regional self-government units 
three-year period. It contains the objectives and priorities for the development of local and regional self-government units associated with the programme and organisational classification of the budget. Furthermore, Art. 33 of the Budget Act states that the administrative bodies of the local and regional self-government units, in cooperation with their respective administrative bodies in charge of finance as coordinators, and pursuant to the strategic documents for the development of local and regional self-government units, shall draw up three-year period development programme plans for the local and regional self-government units. The inclusion of budgetary and extra-budgetary users in the development programme plan is mandatory.

The above indicates that investment projects within the framework of a county's scope of self-governing activities are, for the most part, defined by the development programme plans. As part of the budget, investment projects are adopted by a representative body and carried out by administrative bodies and institutions, public institutions, and companies whose founder or co-founder is the county.

The development programme plan specifies the programmes and investment projects of importance to the county, the administrative bodies and institutions that are project holders, the funds secured in the budget for the current year, as well as the projections of funds required for the next two-year period. Projects implemented by budgetary users (such as port authority, companies (co-)owned by the county, etc.) are not included in the preparation process of development programme plans. Underlined is the need for mutual consideration, joint nomination and subsequent monitoring of the projects that are (co-)financed from the budget, and that have been designated as programmes and projects of importance for the county on the basis of strategic development documents.

The model for the selection and nomination of programmes and projects of county importance, to be included in implementing strategic development documents such as the Action Plan for the implementation of county development strategies, as well as in development programme plans (as a part of the budget that is adopted for $n+2$ years), encompasses the fundamental activities that can ensure the greatest possible impact of public funding relative to overall socio-economic development. 


\section{Strategic Framework for the Implementation of Projects in the Local and Regional Self-Government}

The consideration and nomination of projects and ideas is linked to the principles of "strategic planning" (Albrechts, Healy \& Kunzmann, 2003). Guidelines for the overall development of an area, such as a county, are based on comprehensive development strategies.

The basic strategic documents at the regional level are the county spatial plan and the county development strategy. The obligation to develop these documents stems from legislation. Their content and role in implementing the development policy are clearly stipulated. The initial development document is used to derive the sectoral development documents and the Action Plan in which the projects of interest to the county are unequivocally established, along with the project leader and the sources of funding. It is obligatory for lower-level documents to be consistent with higher-level ones.

\subsection{Spatial Planning Documents}

The spatial articulation of all development plans is determined by spatial planning documents. Spatial plans determine the appropriate organisation, use, purpose of space, and conditions for the development, improvement, and protection of an area (Spatial Planning Act, Official Gazette, 153/13, 65/17, 114/18, 39/19, 98/19). As a rule, they are designed for a planned period of 15 to 20 years. The basic strategic planning document of spatial planning at the county level is the county spatial plan and its counterpart at the local level is the municipality/city spatial plan (Krpan, Milković \&Štimac, 2014).

An integral part of these documents is a list of facilities of importance to the State, the county, and in municipality/city spatial plans, as well as facilities of importance to local self-government units (Krpan, 2011).

\subsection{Planning Documents for Regional Development Policy}

Strategic planning of regional development is achieved through the adoption and implementation of multiannual planning documents (Đulabić \& Čepo, 2017; Mintzberg, 2000; Paasi, 2013). Planning documents of the 
regional development policy are the Regional Development Strategy of the Republic of Croatia, county development strategies, the development strategy of the City of Zagreb, and the urban area development strategy. These documents are issued for a seven-year period in accordance with the multiannual financial framework of the EU cohesion policy. National development documents and spatial plans are the starting points for the preparation of the regional development policy planning documents. County development strategies are implemented via action plans that are compiled for a three-year period, as is the budget. Additionally, the Ministry in charge of regional development is also responsible for the preparation of a long-term strategic platform, acting as an analytical basis for regional development policy management for a minimum of 15 years.

Alongside these documents produced at the local level, overall local development plans are often also produced, although there is no legal obligation or basis for this, nor is the content or purpose of these overall development plans prescribed. ${ }^{2}$

County development strategies are made pursuant to the guidelines for their design, monitoring, and the evaluation of their implementation.

By analysing the time span of strategic documents at the regional level, it is possible to see that county spatial plans are adopted for a period of 15 to 20 years, while the county development strategies are implemented for the duration of the EU financial perspective, that is, for a period of seven years. To ensure their viability and consistency, development documents must be in coherence. Moreover, considering the fact that county development strategies define the vision and the strategic goals, priorities and measures, they should be considered as the basis for the development of spatial planning documents (and not vice versa as allowed by the current legislative solutions). County development strategies are fundamental planning documents for the sustainable socio-economic development of counties, and their mission is to connect local and regional needs with national and European development priorities, as well as with the available European and national funds and regulations that govern their use. The Development Strategy of the Primorje-Gorski Kotar County was created pursuant to the Regional Development Act, and developed in accordance with the logic of project cycle management. In order to collect and identify development projects in the Primorje-Gorski Kotar County, a county database of development

2 According to the Regional Development Act (Official Gazette 147/14, 123/17, 
projects was established, which includes all projects and project ideas that have been aligned with the strategic objectives, priorities, and measures of the Development Strategy, as well as with the priorities and measures for the Adriatic region of Croatia. The collection, evaluation and registration of proposals in the database, together with the selection of projects from the database, are therefore the core processes of the implementation of all priorities and measures of the Development Strategy of the Primorje-Gorski Kotar County.

Figure 1. Flow of strategic thinking up to the selection of projects to be co-financed from the budget

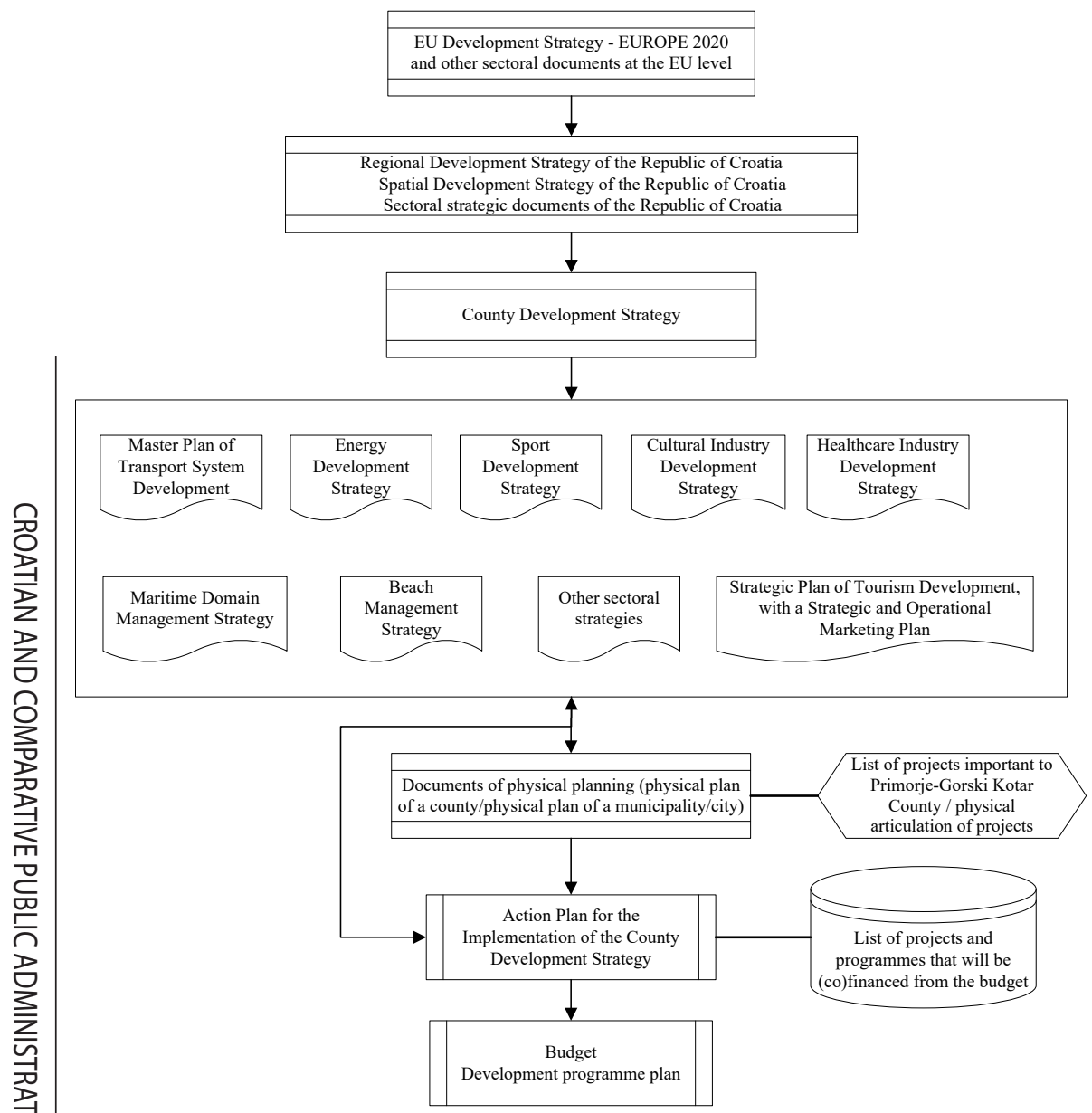

Source: Authors' own construction. 
The projects underlined in the Action Plan for the Implementation of the County Development Strategy and the projects found in the list of facilities of regional importance in the spatial plan of the county, are expected to be the projects selected for operational implementation in the budget period; hence the need for an unambiguous, measurable, and transparent evaluation of projects and their effects, prior to their inclusion first in implementation documents and then in budgets.

\section{Prerequisites for the Inclusion of Projects in the Budgets of Regional and Local Self-government}

The word "project" implies the realisation of an objective in a given period of time (Njavro \& Njavro, 2011). Development projects are all projects, regardless of the stage of their preparation or implementation, that have been recognised by the development project holders, and for which, on the basis of registration in the county database of development projects, public (co-) financing has been proposed and requested. ${ }^{3}$ One of the basic prerequisites for the implementation of projects is the securing of funds for their implementation, including the securing of budget funds (Ermias et al., 2011; Boyone, 2002). Therefore, in order to ensure the full feasibility of projects, they must be properly prepared beforehand. It was often the case in the current practice that what a project essentially consists of was not defined, other than its name.

An unambiguous procedure for nomination, evaluation and selection of projects for co-financing ensures that each project's importance, level of preparedness and impact on the overall development of a given area are realistically identified. Thus, the preconditions are created for the selection and implementation of those projects that will have the greatest developmental impact.

In the Primorje-Gorski Kotar County, project proposals are reviewed and evaluated relative to their developmental impact during the registration of

${ }^{3}$ According to the Regional Development Act (Art. 3), 'development projects' can be projects of construction and/or reconstruction and/or equipping of communal, economic, social, environmental, energy, and other supporting infrastructure for the development, construction, and/or strengthening of educational, cultural, scientific, healthcare, tourism, recreational, sports, and other capacities, as well as other projects that contribute to regional development. 
projects in the County Database of Development Projects. ${ }^{4}$ To this end, the Instructions on the Collection and Evaluation of Development Projects in the Primorje-Gorski Kotar County were adopted. The Instructions determine the method of collection, evaluation, and registration of development projects in the County Database of Development Projects, along with the nomination of projects for their (co-)funding from the Primorje-Gorski Kotar County's budget. The governing bodies of the Primorje-Gorski Kotar County are obliged to apply the Instructions to all county development projects and to the development projects of budgetary users and extra-budgetary users.

The regional coordinator or a legal entity authorised by the regional coordinator (authorised data uploader) is officially authorised to upload data into the County Database of Development Projects. The task of the authorised data uploader is to gather information on development projects from the Development Project Application Form that is filled in by development projects holders who nominate projects. Regardless of a project's stage of completion or its assessed impact on development, the submitted project is registered in the County Database of Development Projects which, following the example of the national database, is non-critical and permanent. In order to determine project readiness, a preliminary evaluation of development projects is performed by an evaluation team following the evaluation criteria and methodology prescribed in the Development Project Evaluation Form. The evaluation team is composed of a representative of the authorised data uploader and a representative designated by the head of the competent budgetary administrative body for the development project which is being evaluated. Exceptionally, if the project has been nominated by a competent budgetary administrative body, the other representative is appointed by the Head of the Administrative Department for Budget, Finances and Procurement. Additionally, the structured instructions encourage project applicants to evaluate the project and make proper feasibility (pre)studies, including socio-economic benefit studies, prior to submitting their application. The project's overall financial indicators (profitability and/or viability) need to be duly demonstrated, and potential financial resources necessary for the project's implementation and subsequent exploitation clearly presented.

${ }^{4}$ The County Database of Development Projects is a collection of data on development projects in the Primorje-Gorski Kotar County. It consists of an electronic database of development projects with a brief overview of basic information about each development project and the forms received from the registry, in electronic and paper form, with more extensive data. Although there is no legal basis for its formation, it has been organised as a tool for the selection and monitoring of the implementation of projects. 


\subsection{Quality Management System as a Lever for Evaluating Development Projects}

According to the ISO 9001 standard, quality management defines the need to recognise goals, position, measure and manage them correctly as a key factor in the development, implementation, and continuous improvement of a business management system. The basic tools for quality policy implementation, in addition to clearly defined objectives, are established joint processes, processes for individual administrative bodies, and work instructions which elaborate these processes in more detail (Žurga, 2008). In the domain of project selection and management, the Primorje-Gorski Kotar County has defined three general processes by means of the ISO 9001 standard. The term "general process" refers to (basic) resource processes which are generally carried out in all organisational units.

Figure 2. Selection and management of development projects

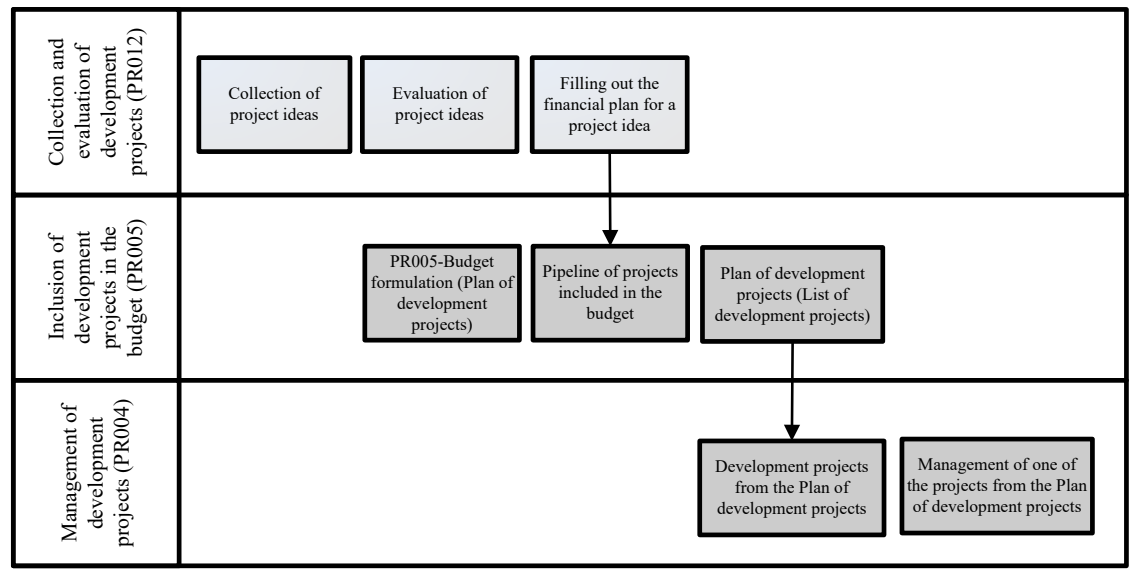

Source: Authors' own construction.

The sequence of activities in the implementation of a project is clearly established. It starts with the process marked as PR-012, "The Process of Collection and Evaluation of Development Projects", which precedes the process PR-005, "Budget Planning and Execution", and is directly linked to the process PR-004, "Management of Development Projects". By connecting these processes, a high level of project proposal preparation is reached, while the possibility of unplanned or arbitrary inclusion of projects in budget (co-)financing is reduced.

A further opportunity to improve project cycle management is provided by the ISO standard 10006, "Quality Management Systems - Guidelines 
for Project Quality Management". It provides guidelines for general use that help to improve the level of quality management in projects, regardless of their shape, volume, area, duration, complexity, involved processes, and the project deliverables. Preferably, the guidelines should be applied by people who are experienced in project management, and driven by the desire for their organisation to achieve excellence and to satisfy all interested parties with the quality, in the manner prescribed by the international family of ISO 9000 standards, across all levels of the organisation. Top management has the greatest responsibility for achieving quality goals, but each organisational level should be responsible for their own specific processes and products. This standard recognises two forms of organisation associated with the project. One is project organisation, which carries out the project and ensures that the final product is satisfying to the customers and all interested parties, while the other is original organisation, which willingly initiates a project (or more of them), and assembles the project organisation(s).

As far as the execution of the project is concerned, it consists of stages and processes that differ conceptually, and both serve the objectives of the project (as mentioned earlier).

\subsection{Evaluation of Projects Registered in the County Database}

In the evaluation of projects nominated for the County Database of Development Projects, the evaluation team should take into account the compliance of the development project with the objectives of the County Development Strategy, the importance of the project in relation to the environment, and the level of completion of project documentation. The overall evaluation score of the development project is in fact the arithmetic mean of the scores given by evaluation team members.

Project application for the County Database of Development Projects consists of filling out the provided application form. The application form gathers basic information about the applicant, as well as information about the project's objectives and the area of its implementation.

Project units should be clearly stated together with information on the readiness of the project for construction (ownership, planning and project documentation, and expected funding sources). Additionally, information on the profitability/viability of the project and on its potential to generate new jobs must also be provided.

The submitted project applications are evaluated by means of the Development Project Evaluation Form, using the weighted factor scoring model 
(Heizer \& Render, 2011). This method consists of six steps: 1. Identifying key factors relevant to the evaluation of the development project (as listed in Table 1); 2. Determining the importance weights for each of the key factors; 3. Determining the scale for each factor (e.g., from 1 to 10 or from 1 to 100); 4. Determining the number of points for each project and each factor based on step 3; 5. Determining the product of importance weights and the number of points associated with each factor as well as the total sum of points; and 6. Making an evaluation of the development project based on the conducted quantitative analysis, i.e., the average evaluation of the project.

Table 1. Development project evaluation form

\begin{tabular}{|c|c|c|c|c|c|}
\hline Critical success factor & 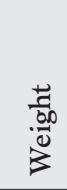 & 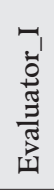 & 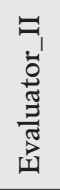 & 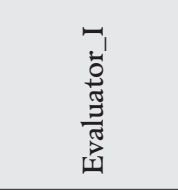 & 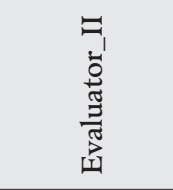 \\
\hline $\begin{array}{l}\text { Project compliance with the } \\
\text { County's Development Strategy }\end{array}$ & 0.1 & 80 & 80 & $(0.1 \times 80)=8$ & $(0.1 \times 8)=8$ \\
\hline $\begin{array}{l}\text { Project importance for target } \\
\text { user groups' needs }\end{array}$ & 0.1 & 85 & 70 & $(0.1 \times 85)=8.5$ & $(0.1 \times 70)=7$ \\
\hline $\begin{array}{l}\text { Sustainability of projected } \\
\text { results after project completion }\end{array}$ & 0.2 & 70 & 75 & $(0.2 \times 70)=14$ & $(0.2 \times 75)=15$ \\
\hline Resolved property-legal relations & 0.2 & 95 & 90 & $(0.2 \times 95)=19$ & $(0.2 \times 90)=18$ \\
\hline $\begin{array}{l}\text { Project implementation } \\
\text { readiness }\end{array}$ & 0.1 & 80 & 70 & $(0.1 \times 80)=8$ & $(0.1 \times 70)=7$ \\
\hline Secured project co-financing & 0.2 & 80 & 85 & $(0.2 \times 80)=13$ & $(0.2 \times 85)=17$ \\
\hline $\begin{array}{l}\text { Project contribution to new } \\
\text { employment }\end{array}$ & 0.1 & 70 & 65 & $(0.1 \times 70)=16$ & $(0.1 \times 65)=6.5$ \\
\hline Total & 1 & & & 80.5 & 78.5 \\
\hline Average grade: & & & & \multicolumn{2}{|c|}{$(80.5+78.5) / 2=79.5$} \\
\hline
\end{tabular}

Source: Authors' own construction.

The data in Table $1^{5}$ show the scores of both evaluators, the overall project scores as well as the average project scores. By changing the number

5 Table 1 presents a concrete example of project evaluation provided in 2019 for "Senior park in Volosko-Opatija". 
of associated points or the importance weight itself, it is possible to analyse the sensitivity of a given project evaluation or the sensitivity of an evaluation between two or more projects.

Figure 3. Flowchart of the procedure of collection and evaluation of development projects

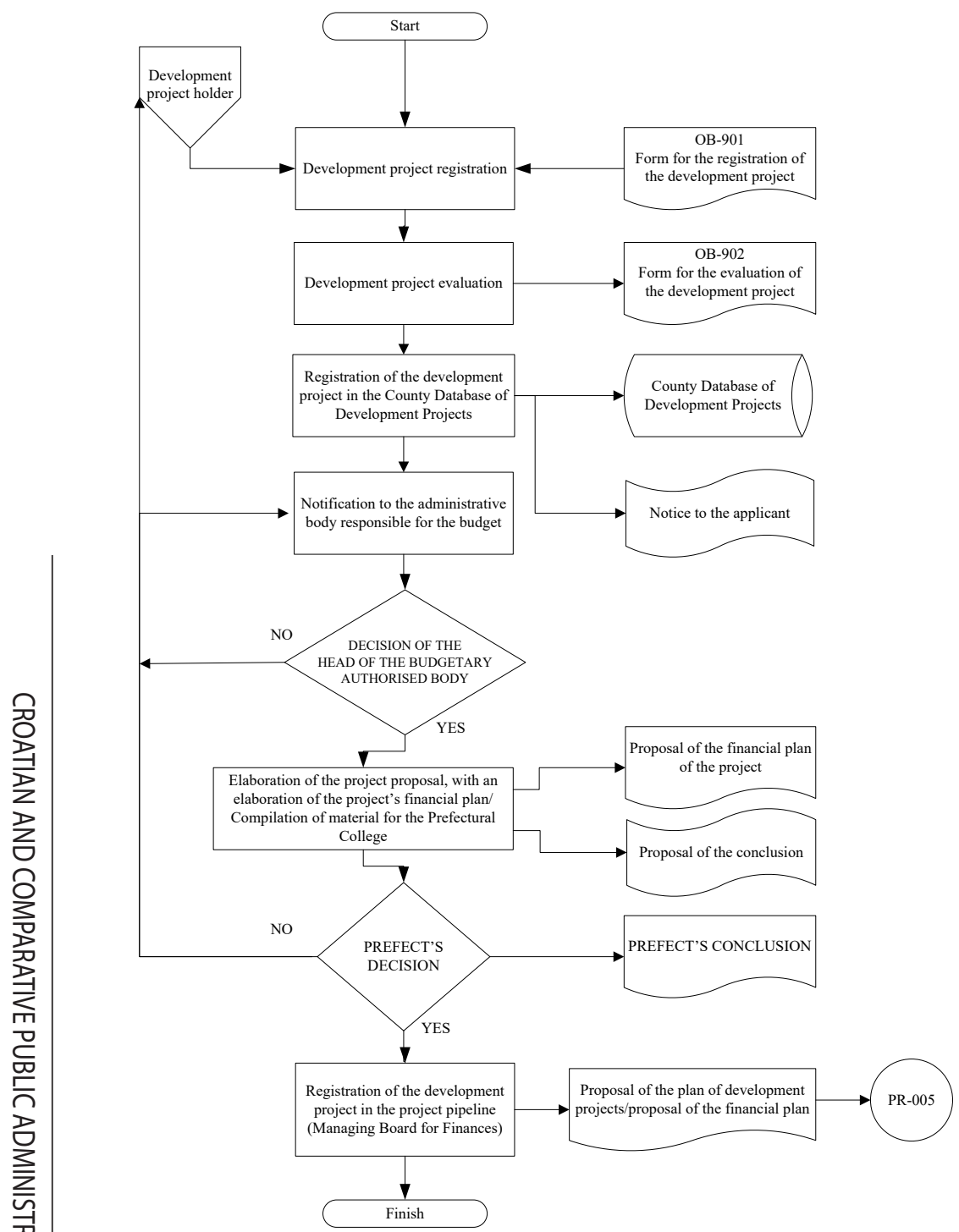

Source: Authors' own construction, based on Quality Management Standards for the Primorje-Gorski Kotar County. (2019). Primorje-Gorski Kotar County, Rijeka, p. 55. 
As mentioned earlier, the overall grade of the project is the arithmetic mean of the score given by both evaluators. The assigned grade serves only as an indication for the head of the responsible department, who, on the basis of the project application (regardless of the project evaluation), assesses whether the project should be submitted for further procedure.

\subsection{Elaboration of Projects Included in the County Database}

The head of the administrative body competent for the budget decides which of the submitted development projects should be elaborated in more detail so as to recommend them for budget (co-)financing. Based on this decision, the applicant of a development project is asked to further elaborate on the project by specifying the activities and funding necessary for its implementation, with special emphasis on its sustainability, relevance and feasibility, that is, its effectiveness.

After being approved by the administrative body competent for the budget, the elaborated development project is submitted to the Prefectural College. The elaboration of the development project must comprise the following, at a minimum: functional and implementation requirements (general and specific objectives); applicable requirements of laws and regulations (legislative and other legal bases); where applicable, information deriving from previous similar projects, and the starting points and indicators on which calculations and estimations of the required resources are based; ways and means of development project implementation, followed by an elaborated financial plan and performance indicators (considering all preparation, construction and exploitation costs of the development project for a minimum of 5 years); other requirements relevant to the development project.

As more complex projects are often implemented over a course of several years, the aforementioned data must be submitted for their entire life spans. Notably, all the listed elements are also a mandatory part of the budget narrative which, as a constituent part of the budget, is adopted by the representative body of the local and regional self-government unit. Thus, they do not represent any additional administrative or bureaucratic burden for the applicants.

Development projects accepted by the decision of the County Prefect (župan) are entered into the pipeline of projects that could potentially be (co-)financed from the County budget. The project pipeline is organised and managed by the administrative body in charge of finances. 
Figure 4. Flow of strategic thinking up to the selection of projects to be co-financed from the budget

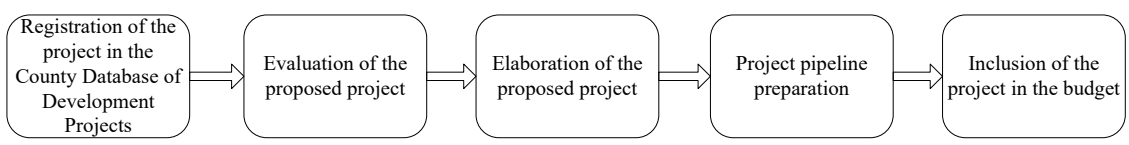

Source: Authors' own construction.

\section{Elaboration of Projects and Programmes According to Their Importance - the Case of the Primorje-Gorski Kotar County}

When choosing activities and projects, it is necessary to determine their significance and role. Project levels are explained below, based on adopted subordinate legislation and the Action Plan for the Implementation of the 2016-2020 Development Strategy of the Primorje-Gorski Kotar County.

\subsection{Elaboration of Projects and Programmes on the Basis of Subordinate Legislation}

Pursuant to the Ordinance on the Establishment, Content, and Management of the Central Electronic Database of Development Projects and Development Indicators, four levels of development projects have been identified: local, county, regional and national projects. Local projects are projects that are important for and impact the development of one or more local self-government units, but are not identified as county projects. County projects are projects that are important for and impact the development of one or more regional self-government units. They are confirmed by the County Prefect and/or the County Partnership Council, but are not classified as regional projects. Regional projects are projects that are important for and impact the development of a statistical region. They are confirmed by the Partnership Council of the statistical region, but are not identified as national projects. National projects are projects of national importance, confirmed by the Government of the Republic of Croatia, at the proposal of the competent Ministry. 
For each development project registered in the database, specific sets of data are defined, such as the entity to be funded, the funding model, and the prepared documentation. Additionally, for projects for which co-financing is sought, the general data on candidates applying for co-financing and financial data on potential sources and amounts of funding must also be submitted.

The Development Projects Database of the Republic of Croatia is organised in this way to ensure the efficient planning, implementation, and monitoring of the regional development policy.

\subsection{Elaboration of Projects and Programmes in the Action Plan of the Primorje-Gorski Kotar County}

When preparing its Action Plan for the Implementation of the 2016-2020 Development Strategy, the Primorje-Gorski Kotar County projected the expected impact on the real sector (the economy). However, the programmes/projects listed were those ensuring improved living and working conditions for citizens residing in the area of their implementation.

The Action Plan for the implementation of the County's development strategies presents programmes and projects that are (co-)financed from the budget of public-law bodies, and that provide a platform from which private entrepreneurial activities can be fostered, either directly or indirectly. A list of programmes and projects is established, whose implementation would ensure the realisation of the adopted vision, strategic goals, priorities and measures of the County Development Strategy.

To be listed in the Action Plan, projects need to have a stronghold in the conducted assessment and evaluation procedure. They have to be accepted by the Prefectural College and included in the list of projects to be implemented. Projects are proposed using the SMART ${ }^{6}$ method of nomination, with the carriers of implementation, planned implementation dynamics, investment amount, and proposal of funding sources clearly specified. ${ }^{7}$ In structuring the Action Plan, special attention is given to

${ }^{6}$ SMART: specific, measurable, attainable, relevant/realistic, time-bound.

7 The Action Plan can underscore which programmes and projects will be nominated and prepared for EU funding, and which will be nominated and prepared through the traditional models of financing or potentially through a public-private partnership, a loan, only through the budget, etc. It can also determine which projects will be prepared at the level of documentation and offered to private investors. In doing so, it is especially important to 
limited financial resources. Hence, projects are prioritised, to avoid listing projects of mere wishful thinking and instead focusing on listing projects with more realistic chances of being delivered. During this process, the readiness of the projects, their implementation timeframe, the required financial resources, the dynamics of project implementation, financial, staff and other capacities of the project developers, and the sustainability of the investment should be taken into account to the greatest extent possible.

The Action Plan for the Implementation of the Development Strategy of the Primorje-Gorski Kotar County is structured in a way that allows it to take into consideration the development programme plan of the Primorje-Gorski Kotar County (in which all budgetary users are included), the development programme plan of the County Road Administration (as extra-budgetary users), and the work plans of all (eight) county port authorities and companies of which the County is a (co-)founder. A prerequisite is that the adopted programmes and projects have been previously evaluated according to the above-described procedure of the development project selection. This ensures the ability to monitor the implementation of the Action Plan by monitoring the Budget Implementation Reports and the Financial Reports of all institutions (co-)owned by the County.

The Action Plan distinguishes between projects of national, county, and local importance. Because the County has no implementation authority or any direct impact on national programmes/projects and local programmes/projects of special importance, detailed indicators of progress, financial allocations, or names of institutions responsible for the implementation of specific programmes and projects are not listed.

As for projects of (supra)national importance, explicitly listed are only the most important infrastructure projects ${ }^{8}$ necessary for achieving the development goals of the Primorje-Gorski Kotar County and whose holder is the Republic of Croatia or a state-owned institution, and projects that the Republic of Croatia has designated as strategic and that are located

take account of the specific areas of the Primorje-Gorski Kotar County (Gorski Kotar and the islands). As the EU in its strategic documents underlines the importance of regional (smart) specialisation, individual economic activities should be efficiently analysed in this segment and the comparative advantages of the Primorje-Gorski Kotar County identified for some of them (e.g., higher education, transport and logistics, IT sector, energy, tourism, shipbuilding, forestry and wood processing, fisheries, pharmaceuticals...).

8 Also not listed are programmes that are financed from national funds and carried out within the territory of the Primorje-Gorski Kotar County but without the County's participation. 
within the territory of the Primorje-Gorski Kotar County. The County will secure logistical support during the implementation of these projects (documents of spatial planning, implementation coordination, participation in the work of project teams...).

Programmes and projects of county importance are structured as:

- programmes/projects that a county and its institutions carry out independently (they can finance a project entirely by themselves or a programme/project can be co-financed from different sources), ${ }^{9}$

- programmes/projects in which a county and its institutions participate as a partner in the implementation of a certain project activity, or co-finance a programme/project in cooperation with other bodies through co-financing,

- projects that are expected to be carried out by a third party (mainly private investors) and whose implementation is monitored (e.g., timeline for the construction of a nautical tourism port or distribution pipeline system, etc.); these are projects that a county has, in accordance with statutory powers, given to third parties for implementation).

Programmes and projects of local significance are listed in the appendix of the Action Plan and represent a synthesis of development needs expressed by local self-government units. The County is not responsible for the operational implementation or co-financing of these projects, simply seeing them as needs specified by the local communities that will be in charge of project implementation.

Given the importance and role of the City of Rijeka, the seat of the Primorje-Gorski Kotar County, projects identified in the 2014-2020 Development Strategy of the City of Rijeka as well as future ones listed in the Urban Agglomeration Development Strategy are itemised in the Action Plan for the Implementation of the Development Strategy of the Primorje-Gorski Kotar County. Their implementation timelines will be monitored by monitoring reports on strategies at the levels at which they have been adopted.

The Action Plan was drawn up with due regard for the development plans of the University of Rijeka. Plans for the University's development, presented in the 2014-2020 Development Strategy of the University of Rijeprojects.

9 Regular and investment maintenance is not included in the mentioned groups of 
ka, have been fully accepted in the Development Strategy of the Primorje-Gorski Kotar County, and the projects listed in the Action Plan have been nominated through the elaboration of projects of national and county interest, and have been further confirmed through the most important projects of the City of Rijeka.

\section{Conclusion}

With Croatia's accession to the European Union, preconditions for further improvements in the management of public finances were created, not only at the national level, but also at regional and local levels. One improvement is the proposed model for selecting projects that are to be financed by local and regional self-government units. The proposed model has been tested in practice and has shown very positive results. It is a fact that public systems are, as a rule, very complex and rigid, even at the regional and local levels, and slow to adjust to change. Hence, the introduction of such clearly prescribed procedures can facilitate the transparent and efficient investment of public funds, while maximising the development impact.

The fundamental characteristics of the applied methodology are linked to identifying and defining the sequence and scope of activities taking place during project selection. Emphasis is placed on the introduction of checkpoints as well as persons and institutions responsible for the implementation of each of the stages being evaluated. The practical research conducted shows that the model demonstrates very good results in financing the projects of local and regional self-government units and their budgetary users. Nevertheless, certain shortcomings, limitations and even resistance to the procedures were observed in both extra-budgetary and budgetary users. Hence, the procedure was additionally developed during testing so that greater responsibility for the procedure was placed on the competent department heads and especially on the supervisory and management boards of budgetary and extra-budgetary users. Two years of testing in the Primorje-Gorski Kotar County indicate that the results of the presented methodology are very good, making the methodology a good framework for the selection of projects in the public sector. 


\section{References}

Albrechts, L., Healy, P., \& Kunzmann, K. R. (2003). Strategic spatial planning and regional governance in Europe. Journal of the American Planning Association, 69(2), 113-129 https://doi.org/10.1080/01944360308976301

Boyone, G. A. (2002). Public and private management: What's the difference. Journal of Management Studies, 39(1), 97-122, https://doi.org/10.1111/14676486.00284

City of Rijeka (2013). Development Strategy of the City of Rijeka. Rijeka, Croatia: Author.

City of Zagreb (2017). Development Strategy of the City of Zagreb for the Period until 2020. Zagreb, Croatia: Author.

Ermias, T., Tekalign, L., Eshetie, B., \& Birhanu, B. (2016). Key project planning processes affecting project success. International Journal for Quality Research, 11(1), 159-172.

Heizer, J., \& Render, B. (10th edition). (2011). Operations management. New York, NY: Pearson.

Džinić, J. (2017). Effective implementation of a quality management policy in public administration: Experiences from Spain and lessons for Croatia. Croatian and Comparative Public Administration, 17(4), 639-664, https://doi. org/10.31297/hkju.17.4.6

Đulabić, V., \& Čepo, D. (2017.). Regionalism and sub-regional representation: A guide to the County transformation of Croatia. Croatian and Comparative Public Administration, 17(4), 539-568, https://doi.org/10.31297/hkju.17.4.2

Krpan, Lj., Milković, M., \& Štimac, M. (2014.). Functional-nodal method of the development of strategic spatial planning documentation. Technical Journal, 21(1), 207-215.

Krpan, Lj. (2011). Analysis of implementing spatial and traffic studies in the development of physical planning documents of Primorje-Gorski Kotar County. Promet. Traffic \& Transportation, 23(1), 71-79, https://doi.org/10.7307/ptt. v23i1.150

Mintzberg, H. (2000). The rise and fall of strategic planning. London, UK: Prentice Hall.

Njavro, Đ., \& Njavro, M. (Fourth Edition). (2011). Vodič kroz znanje o upravlianju projektima. Zagreb, Croatia: Project Management Institute Global Standard. MATE d.o.o.

Paasi, A. (2013). Regional planning and the mobilization of "regional identity": From bounded spaces to relation complexity. Regional Studies, 47(8), 12061219, https://doi.org/10.1080/00343404.2012.661410

Primorje-Gorski Kotar County. Development Strategy of the Primorje-Gorski Kotar County in the Period from 2016 to 2020. Official Journal of the Primorje-Gorski Kotar County 2015, c.34. Retrieved from http://www.sn.pgz.hr/default.as$\mathrm{p}$ ?Link $=$ odluke\&id $=32866$ 
Primorje-Gorski Kotar County. (2019). Quality management standards for the Primorje-Gorski Kotar County. Rijeka, Croatia: Author.

Primorje-Gorski Kotar County. (2015). Instruction on the collection and evaluation of development projects in the Primorje-Gorski Kotar County. Rijeka, Croatia: Author.

Žurga, G. (Ed.) (2008.). Quality management in public administrations of the EU member states: comparative analysis. Ljubljana, Slovenia: Ministry of Public Administration.

\section{Legal sources}

The Budget Act. Official Gazette 147/14, 123/17, 118/18

Ordinance on the Establishment, Content, and Management of the Central Electronic Database of Development Projects. Official Gazette 42/18

Regional Development Act. Official Gazette 147/14, 123/17, 118/18

Spatial Planning Act. Official Gazette, 153/13, 65/17, 114/18, 39/19, 98/19

\section{A FRAMEWORK FOR THE SELECTION OF PROJECTS AT THE COUNTY LEVEL IN CROATIA}

\section{Summary}

According to the Law on Regional Development of the Republic of Croatia, counties are the bearers of regional development in their territories. Hence, the implementation of regional development policies should be based on county development plans, which act as core documents for the selection and implementation of projects co-financed by the EU funds, ensuring the achievement of regional and local development goals. As funds (both budgetary and non-refundable EU funds) are limited and the need for project implementation is significant, the bearers of regional development must credibly assess the most significant development projects and prioritise their implementation. This paper presents the methodology for the effective selection of development projects at the county level, which is also applicable at the local and national levels. The first precondition to a successful methodology was ensuring that all laws and bylaws were considered properly. The presented methodology is primarily based on the application of the mathematical method of weighted factors as the most appropriate method of multi-criteria decision-making. The basic characteristics of the applied method 
are related to determining and defining the sequence and scope of activities in the selection procedure. The emphasis is on the introduction of control points as well as on responsible persons and institutions for the implementation of each of the stages being evaluated. The proposed framework bas been tested in practice and it has shown rather positive results, thus becoming an appropriate project selection framework for the public sector.

Keywords: project management, public projects, county development plan, public project selection, regional development - Croatia

\section{MODEL ODABIRA PROJEKATA NA ŽUPANIJSKOJ RAZINI U HRVATSKOJ}

\section{Sažetak}

Zakonom o regionalnom razvoju utvrđeno je da su županije nositelji regionalnog razvoja na svom području. Provedba politike regionalnog razvoja treba se zasnivati na planovima razvoja županija koji postaju temeljni dokument za odabir $i$ provedbu projekata sufinanciranih sredstvima Europske unije. Oni su podloga za podnošenje $i$ provedbu razvojnib projekata kojima se osigurava ostvarenje regionalnib $i$ lokalnib razvojnib ciljeva. Kako su sredstva (i proračunska $i$ bespovratna sredstva fondova EU-a) ograničena, a potrebe za projektima velike, nositelji regionalnog razvoja moraju vjerodostojno procijeniti najvažnije razvojne projekte te odrediti prioritete u njibovoj provedbi. U radu je predstavljena metodologija učinkovita odabira razvojnib projekata na županijskoj razini koja se može primijeniti $i$ na lokalnu, ali $i$ na nacionalnu razinu. Prvi je preduvjet uspješne metodologije uvažavanje svib propisa. Metodologija se temelji na primjeni matematičke metode težinskog faktora kao najprimjerenije metode višekriterijskog odlučivanja. Temeljne karakteristike primijenjene metode odnose se na odredivanje $i$ definiranje slijeda $i$ obubvata aktivnosti u postupanju pri odabiru projekata. Naglasak je na uvođenju kontrolnih točaka te odgovornib osoba $i$ institucija za provedbu svake od etapa koja se vrednuje. Predloženi okvir testiran je u praksi i nakon višegodišnje primjene pokazao je vrlo pozitivne rezultate te je kao takav dobar okvir za odabir projekata u javnom sektoru.

Ključne riječi: upravljanje projektima, javni projekti, županijski razvojni plan, odabir javnib projekata, regionalni razvoj - Hrvatska 